DOI: $10.11649 / a .1760$

Article No.: 1760

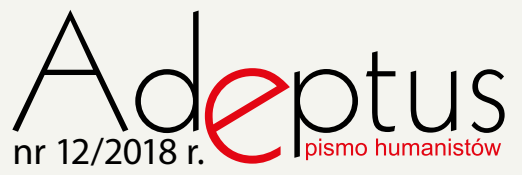

Łukasz Bertram, socjolog, pracuje w Instytucie Socjologii Uniwersytetu Warszawskiego nad doktoratem na temat elity politycznej polskiego stalinizmu, a także przy projekcie dotyczącym kręgu Stanisława Ossowskiego i jego relacji z władzami PRL. Autor książki Wyrodne dzieci nowoczesności. Indultowi tradycjonaliści katoliccy w Warszawie (2016) oraz opracowań PPN. 1976-1981. Język niepodległości (2012) i Obieg NOW-ej (2013); redaktor wspomnień Stanisławy Sowińskiej Gorzkie lata. Z wyżyn władzy do stalinowskiego więzienia (2017). Członek redakcji tygodnika "Kultura Liberalna”. e-mail: lukaszbertram@gmail.com

\title{
Uciec? Dokq̨d? I przed czym? Doświadczenie represji stalinowskich w biografiach członków polskiej elity partyjno-rządowej lat 1949-1956
}

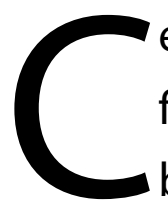

elem niniejszego tekstu jest przedstawienie dramatycznego doświadczenia biograficznego, jakim dla uczestników polskiego międzywojennego ruchu komunistycznego była decymacja jego warstwy przywódczej podczas wielkiej czystki w ZSRR w drugiej połowie lat 30., a następnie likwidacja Komunistycznej Partii Polski (KPP) i podporządkowanych jej organizacji formalną decyzją Kominternu z 16 sierpnia 1938 r. Jako materiał empiryczny wykorzystuję w artykule biografie 214 komunistów1', 22 sympatyków/współpracowników ruchu oraz 5 oficerów Armii Czerwonej, którzy w latach 1949-1956 - a więc w okresie, kiedy Polska przechodziła próbę najdalej idącego upodobnienia do radzieckiego wzorca stalinowskiego - należeli do elity partyjno-rządowej (EPR)². Pozwala to na połączenie refleksji na temat doświadczeń przedwojennych komunistów z analizą grupy wywierającej szczególnie silny wpływ na życie publiczne Polski po Il wojnie światowej. Przyjmuję, że druga

\footnotetext{
${ }^{1}$ Przez „komunistów” rozumiem członków międzywojennej organizacji komunistycznej (partii lub którejś z grup młodzieżowych).

2 Elitę definiuję metodą pozycyjną jako zbiorowość osób zajmujących najwyższe stanowiska w formalnie określonych strukturach politycznych, w tym wypadku - etatowego aparatu oraz gremiów statutowych PZPR oraz instytucji rządowych. Cała tak zdefiniowana przeze mnie EPR liczyła 427 osób.
} 
połowa lat 30. była pod tym względem kluczowym etapem socjalizacji politycznej polskich komunistów - formacji, która stanowiła rdzeń powojennego systemu władzy. Jego kulminacja w roku 1938 była dla nich prawdziwą "fatalną ósemką". Doświadczenie to analizuję zarówno w wymiarze obiektywnym (rodzaj represji), jak i subiektywnym (ich interpretacje dokonywane przez ofiary i świadków).

\section{Decymacja}

Takie założenia wstępne - a także bogata, prezentująca różne tropy interpretacyjne literatura przedmiotu - zwalnia mnie z obowiązku całościowego rekonstruowania i interpretowania genezy, przebiegu i następstw wielkiej czystki (Brzeziński, 1956; Chase, 2002; Conquest, 1997; Getty, 1985; Getty \& Naumov, 1999; Priestland, 2007; Schlögel, 2012; Weissberg-Cybulski, 1990; Wieczorkiewicz, 2016). Los KPP nie doczekał się jeszcze wyczerpującego i całościowego opracowania - jedyną taką próbę podjęto pod sam koniec istnienia PRL (Maciszewski, 1989). Na potrzeby niniejszych rozważań wystarczy skonstatować powszechnie znane fakty. W drugiej połowie lat 30. terror, stosowany dotąd w ZSRR wobec przeciwników partii bolszewickiej, a także różnych grup ludności (takich jak chłopi), obrócił się przeciwko czołowym kreatorom tego systemu - elicie Wszechzwiązkowej Komunistycznej Partii (bolszewików) (WKP(b)). Pod fałszywymi zarzutami szpiegostwa i działalności kontrrewolucyjnej osądzono i rozstrzelano liderów, takich jak Nikołaj Bucharin czy Lew Kamieniew, 98 z 139 członków Komitetu Centralnego z 1934 r. i 7-10\% oficerów Armii Czerwonej. Terror uderzał też w naukowców, artystów, dyrektorów, a także dziesiątki tysięcy zwykłych obywateli. Ocenia się, że w latach 1937-1938 skazano ok. 1,3 mln osób, z czego co najmniej 680 tys. rozstrzelano.

Od początku lat 30. wzrastała też w ZSRR ksenofobia wobec wszystkich "obcych" (Chase, 2002). Dotyczyło to również członków poszczególnych sekcji Kominternu' ${ }^{3}$, mimo że przeszły one w poprzednich latach procesy bolszewizacji i stalinizacji, które doprowadzić miały do przemiany komunistów w zdyscyplinowane armie, podzielające nie tylko ideologię rewolucyjnego przekształcenia świata, lecz także normę posłuszeństwa oraz nieustannej czujności wobec wroga (Chase, 2002; Kołakowski, 2009, ss. 368-370, 396-400; McDermott \& Agnew, 1996, ss. 41-87; Sewell, 2012; Simoncini, 1993, ss. 31-33; Skilling, 1961).

\footnotetext{
${ }^{3}$ KPP, podobnie jak inne partie komunistyczne, były formalnie sekcjami ponadnarodowej Międzynarodówki Komunistycznej, utworzonej w 1919 r., z biegiem lat coraz bardziej podporządkowanej kierownictwu radzieckiemu.
} 
Łukasz Bertram Uciec? Dokąd? I przed czym? Doświadczenie represji stalinowskich w biografiach...

W drugiej połowie lat 30. masowe represje dotknęły centralę Kominternu oraz przebywających w ZSRR lub wzywanych tam komunistów ze wszystkich krajów, gdzie działały ich partie, od Niemiec przez Rumunię po Japonię (Conquest, 1997, ss.441-446; McDermott \& Agnew, 1996, ss. 146-149; Weitz, 1997, ss. 298-300). Aresztowano około tysiąca polskich komunistów, dwie trzecie z nich zginęło lub zmarło w łagrach. Represje objęły co najmniej 75\% wszystkich członków i zastępców członków KC KPP (Kieszczyński, 1989, ss. 198-216; 1992, ss. 293-357). Skazywano ich najczęściej pod absurdalnym zarzutem szpiegostwa dla Polskiej Organizacji Wojskowej (POW) - w rzeczywistości zlikwidowanej w 1918 r., ale „wskrzeszonej” przez radzieckie organa bezpieczeństwa już w pierwszej połowie lat 30. (Cimek, 1990, ss. 113-116; Kochański, 2008).

Niektórzy KPP-owcy przebywający w ZSRR próbowali odsuwać od siebie niebezpieczeństwo, wpasowując się w ówczesną kulturę powszechnej denuncjacji (Chase, 2002, ss. 227-232; Cimek, 1990, ss. 117-120; Shore, 2008, ss. 123-129, 174-181). Komunistom w Polsce trudno było zaakceptować myśl, że ich liderzy mogli być prowokatorami, jednak ogromne znaczenie miały internalizowane od lat zaufanie do ZSRR i Kominternu, norma bezwzględnego posłuszeństwa, warunki konspiracji, w których „doły” nie znały nawet nazwisk przywódców oraz panująca w ruchu atmosfera, w którym braterstwo współistniało z podejrzliwością. Zdezorientowani ludzie szukali racjonalizacji i sposobów na redukcję dysonansu poznawczego (Kalicka, 1989, s. 161; Krzemień, 1982, s. 333; Nalewajko-Kulikov, 2009, s. 106; Schatz, 1991, s. 135). Można w tym wszystkim upatrywać bardzo ludzkiej dyspozycji - trudności przyznania, że to, na czym zbudowało się swoje życie, karierę, wiarę, może być skażone (Chase, 2002, s. 410; Wat, 1990, s. 65). Działały jednak także inne mechanizmy. Gdy pewna komunistka zaczęła krytykować procesy wybitnych bolszewików, to "o mało co nie zadręczono jej całkowicie”, przez co należy rozumieć zarówno groźby ze strony towarzyszy, jak i presję moralną przez nich wywieraną. Mniej wyrobionym działaczom nie przekazywano też pełnej informacji

\section{Likwidacja}

W polską partię uderzono najmocniej ze wszystkich. Jako jedyna została nie tylko przetrzebiona, lecz także rozwiązana - jako całkowicie przeżarta „prowokacją” (Cimek, 1990, ss. 127-131, 166-169; Kochański, 2008; Kowalski, 1975, ss. 384-433; Maciszewski, 1989). Decyzja ta wyjaśniana jest na różne sposoby, kluczową rolę odgrywała chyba jednak szczególna bliskość

\footnotetext{
${ }^{4}$ We wszystkich zapisach, jeśli nie zaznaczono inaczej, została zachowana oryginalna ortografia i interpunkcja. AAN, Zbiór Relacji Dotyczących Ruchu Robotniczego (ZRDRR), R-192, Fania Herman, 8 II 1966, k. 191, Stefania Olczak, 8 II 1966, k. 167.
} 
polskich komunistów i bolszewików (McDermott \& Agnew, 1996, s. 147). Przed 1918 r. działali oni w ramach jednego państwa, a Socjaldemokracja Królestwa Polskiego i Litwy (SDKPiL) była autonomiczną częścią Socjaldemokratycznej Partii Robotniczej Rosji (SDPRR). Polscy komuniści starszego pokolenia byli nie tyle uczniami, co towarzyszami Lenina - i dobrze pamiętali czasy, kiedy Stalin nie był wodzem światowego proletariatu. Tym samym zarówno oni, jak i młodsi działacze, dla których stanowili wzorce osobowe i polityczne, byli wystarczająco „obcy”, by zgładzić ich jako sanacyjnych szpiegów i prowokatorów - i wystarczająco "swoi", by potraktować ich tak samo jak „starych bolszewików".

Dla komunistów Partia nie była tylko narzędziem politycznym. Była świętością, sensem życia. François Furet (1996, s. 149) określił ją jako hipostazę historycznej boskości, Ken Jowitt pisał o jej zinstytucjonalizowanej charyzmie (Müller, 2016, s. 51). Była nadrzędna wobec jednostki, jej dobro miało być naczelnym imperatywem etycznym. Służba idei przeobrażała się w służbę partii, ta natomiast - w posłuch wobec kierownictwa (Hirszowicz, 2001, s. 45). Trajektorie biograficzne wiodły od akcesu do ruchu zgodnie z nonkonformistycznymi i altruistycznymi marzeniami o lepszym świecie - do stanowiska, że może dokonać tego tylko konkretna organizacja (Levy, 2001, s. 56). Wezwania do posłuszeństwa, dyscypliny i scedowania samosterowności na rzecz Partii odpowiadały przy tym indywidualnym potrzebom i aspiracjom wielu komunistów (McDermott \& Agnew, 1996, ss. 15, 25, 60; Werblan, 2009, ss. 33-36). Bolszewizację i stalinizację trudno zatem postrzegać jako prostą dychotomię "totalitarnej" struktury, jednokierunkowo oddziałującej na bierne jednostki. Organizacja nie była tylko armią, ale również wspólnotą, prawdziwą grupą odniesienia dającą poczucie przynależności, zapewniającą bezpieczeństwo i akceptację. Komuniści powszechnie porównywali ją do najbliżej rodziny (Krzemień, 1982, s. 166; Ludwińska, 1988, ss. 24-25). Był to zresztą element ówczesnego ducha epoki (Kijek, 2017, ss. 328-344). Oczywiście nie wszyscy komuniści byli pod tym względem tacy sami, a relacja między modelem idealnego rewolucjonisty a rzeczywistymi praktykami była pełna napięć i niekonsekwencji.

Rozwiązanie KPP w "fatalnym roku 1938" było więc gigantycznym szokiem. Cios spadł z najmniej oczekiwanej strony. Wysłannicy z ZSRR meldowali zarówno o zaufaniu polskich komunistów wobec Kominternu, jak i braku akceptacji dla jego decyzji (Kowalski, 1975, s. 432; Nazarewicz, 1989, s. 153). Zdarzały się samobójstwa ${ }^{5}$. Wraz z partią kończyło się coś

${ }^{5}$ AAN, ZRDRR, R-114, Edwarda Orłowska, 27 XI 1961, k. 30. 
podstawowego, najbliższego, co nadawało sens życiu; ludzie czuli się zdezorientowani, zdradzeni, pozbawieni rodziny i domu. Odczytywaniu uchwały Kominternu towarzyszyły łzy i nastrój żałoby. Nagle zabrakło nie tylko sacrum oraz wspólnoty, ale też struktury, która do tej pory przekazywała wytyczne, wskazywała kierunki, porządkowała świat.

\section{Doświadczenia członków elity partyjno-rządowej}

Pod względem rodzaju doświadczeń przeżywanych w tym okresie, komunistów polskich można podzielić na cztery grupy. Pierwszą z nich są ofiary śmiertelne czystki. Drugą - osoby osadzone w więzieniach lub łagrach. Trzecią - ci, którzy stracili swoich najbliższych, bądź których znaczący inni przeżyli więzienie lub obóz. Czwarta kategoria to ludzie, których takie doświadczenia nie dotknęły w bezpośredni sposób. Byli wśród nich zarówno działacze wyższego szczebla, którzy dobrze znali represjonowanych i orientowali się przynajmniej w części mechanizmów politycznych, jak i zwyczajni uczestnicy ruchu, członkowie komórek w śląskich kopalniach, wołyńskich wsiach i kieleckich warsztatach. Wszystkich, niezależnie od losów osobistych, dotknęło natomiast rozwiązanie partii.

Wśród członków EPR znaleźli się przedstawiciele trzech ostatnich grup. Były to osoby, które nie tylko dożyły 1948 r., lecz także nie zerwały trwale z komunizmem, a po wojnie znalazły się na najwyższych szczeblach władzy. Ich biografie pokazują na tyle szerokie spektrum doświadczeń, że pozwalają na refleksję nie tylko o tym gronie, lecz także o polskich komunistach jako takich.

\section{Represjonowani osobiście}

Ofiarami bezpośrednich represji padło 17 członków elity partyjno-rządowej: 13 komunistów ¡ 4 oficerów Armii Czerwonej. Największą część aresztowanych stanowiło osiem osób ${ }^{6}$, które większą, a przynajmniej znaczną część dotychczasowego życia spędziły w ZSRR, gdzie naturalnym środowiskiem życia stała się dla nich międzynarodowa wspólnota komunistów (Schlögel, 2012, ss. 438-447). Co więcej, ich socjalizacja polityczna obejmowała wieloletnie doświadczenie, nabywane w kraju, w którym ruch komunistyczny zdobył władzę.

\footnotetext{
${ }^{6}$ Celina Budzyńska, Teodora Feder, Władysław Kotlarski, Eugenia Kubowska, Franciszek Mazur, Jadwiga Siekierska, Julian Tokarski, Elżbieta Zajączkowska.
} 
Od początku lat 30. obcowali z jeszcze silniejszą niż w Polsce normą dyscypliny i czujności, a także procesem przedzierzgania się rewolucjonistów w biurokratów (Fitzpatrick, 2012, ss. 26-27; Lewin, 1985, ss. 236-240).

Kolejne trzy osoby, Ludwika Jankowska, Józef Kowalczyk i Stefan Staszewski, choć w okresie międzywojennym przyjeżdżały do ZSRR, były przede wszystkim wieloletnimi "funkami", etatowymi działaczami podziemnego ruchu komunistycznego w Polsce. To właśnie tacy „zawodowi rewolucjoniści” całkowicie poświęcający się działalności politycznej, przerzucani z miejsca na miejsce, zahartowani w więzieniach, stanowili kręgosłup partii („O bolszewizacji partii”, 1955, ss. 122-139). Jankowska i Staszewski byli typowymi „funkami”, Kowalczyk przez długi czas działał też w redakcjach legalnych pism KPP. Inaczej wyglądały kariery Zygmunta Modzelewskiego i Władysława Wolskiego. Obaj zaczynali na początku lat 20. od pracy konspiracyjnej, jednak potem duża część aktywności Wolskiego przypadła na pracę w biurze Stefanii Sempołowskiej, sprawującej opiekę nad więźniami politycznymi w Polsce z ramienia Rosyjskiego Czerwonego Krzyża, zaś Modzelewski kilkanaście lat działał we Francji, gdzie komuniści funkcjonowali oficjalnie.

Trzej członkowie EPR zostali aresztowani w ZSRR już w 1935 r., co mogło uratować im życie - wtedy polskich komunistów z reguły jeszcze nie zabijano. Julian Tokarski przed wyjazdem w 1929 r. do ZSRR na leczenie był m.in. sekretarzem KC Związku Młodzieży Komunistycznej (ZMK). Ukończył Międzynarodową Szkołę Leninowską kształcącą kadry „zawodowych rewolucjonistów", nie wrócił jednak do kraju, lecz pracował w radzieckim aparacie partyjnym. W sierpniu 1935 r. został aresztowany i oskarżony o przynależność do POW. Jak sam pisał: „na ile to było wszystko (?), bezpodstawne świadczy choćby, że śledztwo nie zostało zakończone, że żadnego sądu nie było i nie mogło być (...) i nawet w decyzji (...) nie było wskazane artykułu za co zostałem skazany na 5 lat obozu pracy"7. Wyrok ten odbył na Sołowkach. Kowalczyk został aresztowany w listopadzie 1935 r., przybywał w obozach w Komi i pod Wołogdą do listopada 1939 r. Dzięki wyniesionej z Iwowskiego gimnazjum znajomości łaciny znalazł zatrudnienie przy zaopatrzeniu medycznym ${ }^{8}$. Trzecia z ofiar 1935 r., Władysław Wolski, z ruchem rewolucyjnym związała się jeszcze w czasach SDKPiL. Wolski nie był typem zdyscyplinowanego wykonawcy poleceń, a raczej jednostką aspirującą do odgrywania w ruchu podmiotowej roli. Odmawiał samokrytyki, czyli podstawowego stalinowskiego rytuału (Fitzpatrick, 2012, ss. 27-28), a po przyjeździe do Moskwy

\footnotetext{
${ }^{7}$ AAN, KC PZPR, Biuro Spraw Kadrowych (BSK), 237/XXIII-888, Julian Tokarski, uzupełnienie do życiorysu, 5 V 1944, k. 14-15.

${ }^{8}$ Korespondencja mailowa autora z Marią Rotstein, 2 VI 2018.
} 
Łukasz Bertram Uciec? Dokąd? I przed czym? Doświadczenie represji stalinowskich w biografiach...

wolał pracować w wyuczonym zawodzie elektrotechnika niż w środowisku politycznym, z którym był zresztą skonfliktowany (Wolski, 1980, ss. 27-28) ${ }^{9}$. Aresztowano go w listopadzie 1935 r., z łagru wyszedł na przełomie 1940 i 1941 r.

Podczas apogeum wielkiej czystki aresztowano ośmioro komunistów. Biografia Jadwigi Siekierskiej, która całe życie do 1945 r. spędziła w Rosji, to opowieść o frenetycznym urzeczeniu córki polskiego szewca-socjalisty rewolucją. Dla nastoletniej nauczycielki „[p]raca w szkole i burzliwe wydarzenia w kraju, odkrywcza lektura i marzenia o wielkim życiu i o wielkiej miłości - był to splot oszałamiających myśli i wzburzonych uczuć" (Siekierska, 1960, s. 22). Zaangażowawszy się w działalność w kręgu polskich komunistów, pozostawała "w stanie euforii, dumn[a] z przekształcania świata, z wielkości spełnionej dziejowej misji” (Siekierska, 1960, s. 77). Długo wykładała w kominternowskich szkołach politycznych. Aresztowano ją w czerwcu 1937 r., tego samego dnia co męża, Stanisława Bobińskiego, działacza i publicystę KPP. On zginął, ona zaś spędziła osiem lat na dalekiej Północy.

Wyczerpującą narrację o losach swoich i Siekierskiej pozostawiła we wspomnieniach Celina Budzyńska (1997, ss. 291-452; Torańska, 2004, ss. 21-37). Pochodziła z rodziny o korzeniach szlacheckich i żydowskich oraz - po obu stronach - insurekcyjnych tradycjach, od końca XIX w. silnie związanej z ruchem socjalistycznym oraz komunistycznym. Pisała, że do wstąpienia do Związku Młodzieży Komunistycznej przygotowało ją całe jej, wówczas piętnastoletnie, życie (Budzyńska, 1997, s. 155). Od 1926 r. mieszkała w ZSRR i związała się z działaczem KPP Stanisławem Budzyńskim. Ostatnie miesiące wspólnego życia spędzili w gęstniejącej atmosferze, gdy znikali kolejni przyjaciele. Jeden z nich niedługo przed własnym aresztowaniem próbował siebie i ją samą gorączkowo przekonywać, że może w oskarżeniach jest coś na rzeczy, skoro np. ktoś miał ojca w Polskiej Partii Socjalistycznej (PPS). Ripostą, że jej rozmówca ma brata endeka, wywołała u niego atak panicznej wściekłości (Budzyńska, 1997, s. 272). Gdy w czerwcu 1937 r. NKWD zabrało jej męża, ostatnim, co od niego usłyszała, była prośba, by jeśli może, wierzyła w jego niewinność (Budzyńska, 1997, s. 284). Po samą Budzyńską enkawudziści przyszli miesiąc później. We wspomnieniach szczegółowo opisała swoją ośmioletnią odyseję od celi pełnej zdezorientowanych żon „wrogów ludu" po kolejne obozy, ukazała szeroki przekrój ludzkich postaw, obraz ośmioletniej łagrowej codzienności, zapis lęku o los dwóch córek, wreszcie świadectwo walki o uratowanie godności.

\footnotetext{
${ }^{9}$ Korespondencja mailowa autora z Antonim Wolskim, 21 IX 2018.
} 
Łukasz Bertram Uciec? Dokąd? I przed czym? Doświadczenie represji stalinowskich w biografiach...

Ludwika Jankowska przez wiele lat sprawowała ważne funkcje w - autonomicznej w ramach polskiego ruchu - Komunistycznej Partii Zachodniej Białorusi. W 1937 r. docierały do niej niepokojące sygnały z Moskwy, gdzie przebywał jej mąż Stefan Martens-Skulski. Sądziła, że zebrane przez nią materiały o działalności partii mają wielkie znaczenie. Dlatego też dążyła do tego, by przyspieszyć swój wyjazd do ZSRR. Zastała tam zaplombowane drzwi i ani śladu męża i syna. W siedzibie Kominternu dowiedziała się jedynie, że „jeśli będę żyć, to mi dziecko zwrócą". Następnego dnia została aresztowana, po czym skazano ją na osiem lat łagru. Po latach próbowała odpowiedzieć na pytanie, dlaczego ona, jej mąż i inni jechali do ZSRR pełni złych przeczuć: „A jak było nie pojechać? Uciec? Dokąd?

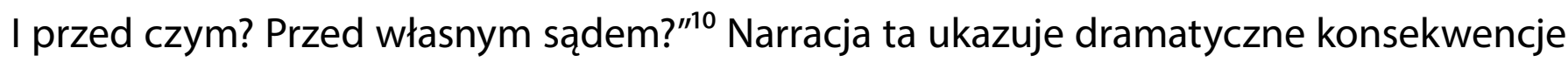
socjalizacji w ruchu komunistycznym. „Zawodowych rewolucjonistów”, dla których jedyną od lat grupą odniesienia była partia, przerażała myśl o znalezieniu się w pustce. Stał za tym lęk przed rolą renegata, ale też uwewnętrznione przekonanie, że ruchowi należy oddać całego siebie.

We wrześniu 1937 r. do Moskwy wezwano też z Francji Zygmunta Modzelewskiego i zaraz potem aresztowano. Przeszedł przez bardzo ciężkie śledztwo - nie tylko bicie, lecz także przetrzymywanie w lodowatym karcerze. Zrujnowało mu to zdrowie i prawdopodobnie przyczyniło się do przedwczesnej śmierci (Modzelewski, 2013, ss. 14-15). Po zwolnieniu w lipcu 1939 r. nie obawiał się odwiedzić domu Stefana i Wiktora Lederów, w których rodzinie z siedemnaściorga zaangażowanych komunistów zginęło dwanaście osób. Zapamiętali oni jego łzy (Leder \& Leder, 2005, ss. 17, 253-254).

Stefan Staszewski, który był m.in. sekretarzem komunistycznej młodzieżówki, wpadł w kłopoty już po przybyciu do Moskwy w 1934 r. Najpierw zmuszono go do samokrytyki za to, że był współautorem listu krytykującego władze KPP, co nie mieściło się w kulturze politycznej ruchu, ukrywającego wszelkie rozbieżności pod fasadą jedności - mimo że w praktyce frakcje i koterie nigdy nie zniknęły. Staszewski napisał więc m.in.: „wykazałem brak zrozumienia elementarnych obowiązków swoich względem partji, że jako komunista i profesjonalny rewolucjonista winien jestem partji oddać wszystko aż do życia swego, ale nie mam prawa nic żądać od partji walczącej w niesłychanie ciężkich warunkach" (Juzepczuk, 2017, s. 46). Czy było to świadectwo płynące z głębokiego przekonania i chęci przezwyciężenia tych „naleciałości” (Halfin, 2003), czy raczej taktyka i umiejętność „"mówienia po bolszewicku” we własnym interesie

${ }^{10}$ AAN, ZRDRR, R-114, Ludwika Jankowska, 2 XII 1961, s. 12-20. 
(Kotkin, 1997, ss. 215-237)? Na razie otrzymał tylko naganę, jednak po niecałym roku usunięto go z pracy i z WKP(b). W listopadzie 1937 r. aresztowano go, ale osądzono dopiero w 1939 r. Był to już czas pewnej odwilży, więc może dlatego Staszewski mimo oskarżenia o przynależność do POW został skazany "tylko" na 15 lat łagru (Juzepczuk, 2017, ss. 43-64).

Eugenia Kubowska, studentka biologii, do ZSRR przyjechała pod koniec lat 20. Pracowała w szkolnictwie oraz w kaukaskim sowchozie, którym kierował jej mąż Jakub Cyterszpiller-Kubowski, niegdyś jeden z liderów ZMK. Aresztowano ją w sierpniu 1937 r. i skazano na 10 lat. Do 1945 r. przebywała w łagrze niedaleko Karagandy. Męża rozstrzelano, ośmioletni syn trafił do domu dziecka, a niedawno urodzona córeczka zmarła w drodze do obozu". Władysław Kotlarski w Polsce działał do 1924 r., a następnie skierowano go do pracy w moskiewskiej centrali Międzynarodówki Chłopskiej. Tej decyzji syn robotnika, niegdyś piekarz, zawdzięczał również awans społeczny, gdyż w ZSRR ukończył studia. Po aresztowaniu w 1937 r. spędził 8 lat w kilku syberyjskich obozach, m. in. w Uchcie. Elżbieta Zajączkowska w wieku 16 lat wstąpiła do SDKPiL. W 1927 r. trafiła do ZSRR, gdzie - tak jak w Polsce - pracowała jako robotnica i pracowniczka partyjna. Po aresztowaniu trafiła na 8 lat na Kołymę.

Dwoje ostatnich komunistów aresztowano dopiero w 1940 r., ale można uznać ich za spóźnione ofiary wielkiej czystki. Teodora Feder była prawdziwą międzynarodową komunistką. Jako gimnazjalistka z dobrze sytuowanej rodziny zachwyciła się pismami Róży Luksemburg (jej drugą fascynacją była Maria Skłodowska-Curie) ${ }^{12}$. Do ZSRR trafiła już w 1923 r. Z ramienia Kominternu wyjeżdżała do Chin i Francji, a podczas hiszpańskiej wojny domowej (1936-1939) pracowała w ambasadzie ZSRR. Franciszek Mazur wreszcie wywodził się z rodziny ukraińskojęzycznych chłopów lub robotników rolnych, podczas rewolucji służył w rosyjskiej flocie. Pozostał w ZSRR, ukończył studia i został prezesem Sądu Najwyższego Ukraińskiej SRR. W 1930 r. skierowano go do pracy w kierownictwie drugiej organizacji autonomicznej, Komunistycznej Partii Zachodniej Ukrainy, która dopiero co przeszła poważny rozłam (Radziejowski, 1976, ss. 139-239; Zajcew, 2015). Trafił do polskiego więzienia i w ZSRR znalazł się dopiero w 1939 r. Być może doniesiono, żew 1937 r. nie zgadzał się z obowiązującą wykładnią na temat trockizmu, więc NKWD aresztowało go za „antysowiecką" propagandę.

W skład EPR wchodziło również kilku wysokich rangą oficerów przedwojennej Armii Czerwonej. Najbardziej znanym z nich jest oczywiście Konstanty Rokossowski, pozostali

\footnotetext{
${ }^{11}$ Rozmowa telefoniczna autora z Jerzym Kubowskim, 5 VI 2018, notatki w zbiorach autora.

12 Relacja Pawła Mandaliana nagrana przez autora, 12 I 2016, transkrypcja w zbiorach autora.

${ }^{13}$ AAN, BSK, 237/XXIII-717, informacja, 13 II 1945, k. 7; życiorys niewiadomego autorstwa, 1944, k. 11-12.
} 
to Jerzy Bordziłowski, Władysław Korczyc, Stanisław Popławski oraz Bronisław Półturzycki. W okresie wielkiej czystki represjonowani byli wszyscy prócz Popławskiego, który został jedynie czasowo usunięty z wojska. Korczyca ponoć bito wyciorami od karabinów, po pewnym czasie późniejszy szef sztabu generalnego WP zaczął podawać śledczym nazwiska z Trylogii Henryka Sienkiewicza. Rokossowskiemu wybito kilka zębów i połamano żebra (Wieczorkiewicz, 2016). Wszystkich czterech oficerów zwolniono do marca 1940 r.

\section{Represjonowane rodziny}

Partnerów życiowych straciło w czystce dziesięcioro komunistów z elity stalinowskiej. Dotyczy to zarówno mężów/żon ${ }^{14}$, z którymi byli związani w momencie aresztowania, jak i byłych partnerów, z którymi jednak rozstali się relatywnie niedługo przed czystką. Z takimi osobami łączyła ich nie tylko pamięć o wspólnych doświadczeniach, lecz także dzieci. Mężów straciły wymienione wcześniej Budzyńska, Feder, Jankowska, Kubowska i Siekierska. Z wyjątkiem męża Feder, działacza pochodzenia ormiańskiego, byli to KPP-owcy. Zginął też mąż weteranki polskiego socjalizmu i komunizmu Marii Pieczyńskiej, jeden z ideologów partii Jerzy Heryng, a także partnerzy trzech „zawodowych rewolucjonistek" - Romany Granas, Heleny Kamińskiej i Marii Kamińskiej ${ }^{15}$. W tych trzech przypadkach nie udało mi się ustalić, czy związki te trwały w momencie aresztowań, H. Kamińska miała natomiast syna, którego dopiero po 1939 r. odnalazła w domu dziecka (Kalicka, 1989, s. 179). Zginęła pierwsza żona Ostapa Dłuskiego, członka najwyższych instancji partyjnych. Jak widać, w gronie tym dominowały kobiety. W kontraście do pejoratywnego określenia "ciotek rewolucji” używanego po wojnie na określenie starszych wiekiem, dogmatycznych komunistek, można więc mówić również o znacznie bardziej tragicznej figurze "wdowy rewolucji” (Bertram, 2017).

Siedem osób utraciło kogoś z rodzeństwa. Z aresztowanych byli to Siekierska i Staszewski - zginęli jej apolityczna siostra i jego brat, który kiedyś wprowadził go w środowisko komunistyczne. Rozstrzelani zostali też bracia Józefa Kowalskiego, Stanisława Radkiewicza i Stanisława Tkaczowa ${ }^{16}$, a także siostra Zygmunta Kratki. Brata stracił również Jan Trusz. Czystka pochłonęła też stryja Romany Granas, szwagra Aleksandra Zawadzkiego oraz wuja

\footnotetext{
${ }^{14}$ Działacze komunistyczni bardzo często nie formalizowali swoich związków, ale określenia „mąż” i „żona” były w powszechnym użyciu.

${ }^{15}$ Bolesław Łukaszewicz, Antoni Lipski (ostatni kierownik Sekretariatu Krajowego KPP) oraz Henryk Kossowski. Na temat fascynującej biografii M. Kamińskiej zob. Bertram 2016.

${ }^{16}$ Ferdynand Tkaczow był działaczem KPP i jej legalnych przybudówek, posłem na Sejm II RP.
} 
Władysława Matwina. Prawie wszyscy byli „zawodowymi rewolucjonistami”, ze stażem sięgającym głęboko w lata 20. Odmienne było doświadczenie Trusza, lokalnego działacza z ukraińskiej wsi pod Chełmem, który łączył aktywność polityczną z codzienną pracą w gospodarstwie, a także Matwina, studenta uniwersytetu.

Łagry przeżyły siostry Jankowskiej i Radkiewicza oraz brat Siekierskiej. Uratowała się też siostra Gertrudy Pawlak-Finderowej, brat Marii Rutkiewicz, teściowa Wolskiego ${ }^{17}$ oraz pierwsze żony Kowalczyka i Włodzimierza Zawadzkiego, który tak jak Radkiewicz wchodził w skład ostatniego kierownictwa partii. Pierwszy, a potem trzeci mąż Celiny Budzyńskiej, Zygmunt Trawiński, spędził w obozach 21 lat.

\section{Świadkowie decymacji, ofiary likwidacji}

Roman Nowak, górnik, a potem wieloletni funkcjonariusz KPP, tak wspominał dezorientację komunistów przebywających w Pradze czeskiej: „jeden na drugiego patrzył krzywo, podejrzliwość była większa jak zawsze". Zastanawiali się nad „zarzutami” wobec przywódców partii, wyszukując takie elementy "pracy, znajomości, powiązań, atmosfery”, które mogłyby je uzasadnić. Według niego działacze jadący do Moskwy często wiedzieli, że będą aresztowani, a mimo to pisali - on również - listy, by ich wezwano. Po latach stwierdził, że wszyscy byli frajerami ${ }^{18}$. Narracja ta ukazuje, jak na sposobie myślenia KPP-owców odbijała się spiskowa wizja świata, ale też świadomość, że policyjni agenci w ruchu byli jak najbardziej realni; przybliża również strategię racjonalizacji absurdalnej rzeczywistości. O tym zaś, że nie wszyscy byli "frajerami” świadczyć może historia Franciszka Fiedlera, czołowego teoretyka KPP od wielu lat mieszkającego na Zachodzie. Krąży opowieść, że gdy wezwano go z Paryża, udał chorego. Tadeusz Daniszewski przywołał natomiast atmosferę panującą w kraju. Gdy miano go zwolnić z więzienia mimo poważnych zarzutów, zaczęła go trapić myśl, że mimo nienagannej, piętnastoletniej kariery w podziemiu i centrali Kominternu, będzie „pisywał kolejne życiorysy, wypełniał kolejne ankiety, a sprawa tajemniczego zwolnienia mego wciąż rzucać będzie cień na mają godność i uczciwość rewolucjonisty". Ulgę przyniosło mu wysłanie do obozu internowania w Berezie Kartuskiej ${ }^{19}$.

\footnotetext{
${ }^{17}$ Helena Bobińska - pierwsza żona wspominanego wcześniej Stanisława.

${ }^{18}$ Wszystkie cytaty za: AAN, Akta Romana Nowaka, 479/9, rozmowa z Romanem Nowakiem, 28 VIII 1961, k. 22, 24, uzupełnienie do rozmowy, 9 X 1963, k .9-10; Roman Nowak, relacja, 2 XI 1961, k. 52.

${ }^{19}$ AAN, Akta Tadeusza Daniszewskiego, 466/3, Tadeusz Daniszewski, Między Mokotowem a Centralniakiem, k. 45.
} 
Edwarda Orłowska, członkini sekretariatu KC Komunistycznej Partii Zachodniej Białorusi, nie chciała wierzyć w napływające informacje o zagładzie kierownictwa i próbowała rozwijać działalność, by pokazać, że partia żyje ${ }^{20}$. Jan Izydorczyk, członek KC KPP, nie wierzył podobno w oskarżenia wobec przywódców i obawiał się, że wokół niego również gromadzą się podejrzenia. Ponoć właśnie dlatego we wrześniu 1939 r. nie ruszył w kierunku ZSRR (Gomułka, 1994, ss. 447-448) $^{21}$.

Marian Naszkowski, młody Iwowski polonista, który został "funkiem" w robotniczych okręgach naftowych, wspominał ,że nim i innymi kierowało bezkrytyczne zaufanie do Stalina i ZSRR (Naszkowski, 1965, s. 110). Znacznie bardziej doświadczony Leon Kasman, komunista od 1920 r., wykładowca wspominanej „leninówki”, uważał, że sytuację trzeba przeczekać (Torańska, 2004, s. 437). Wilhelmowi Billigowi ciężki czas pozwoliła przetrwać komuna więzienna, która organizowała całość życia więźniów politycznych. Gdy wyszedł na wolność, myślał: „jak to dobrze było siedzieć w więzieniu. Ta spójnia kolektywu, która była i to że tam partia działała i pracowała"22. Leon Bielski wraz z towarzyszami z celi uczcił w 1938 r. rocznicę rewolucji, widział jednak również komunistów, którzy nie wytrzymywali nerwowo atmosfery lub próbowali załatwiać osobiste porachunki, rzucając na innych oskarżenia o trockizm ${ }^{23}$. Trusz napisał we wspomnieniach jedynie o „bolesnym ciosie” i głuchym milczeniu w celi po ogłoszeniu uchwały Kominternu (Trusz, 1981, s. 92). Przebywający wówczas na wolności Roman Zambrowski zwrócił uwagę na szczególny, osobisty wymiar likwidacji KPP: jako "nielegalnik" od dziesięciu lat, nie miał wyuczonego zawodu ani domu, znalazł się w próżni (Zambrowski, 1965, ss. 401-402). Zdyscyplinowaniem wykazał się inny "funk" Ferdynand Chaber, który ukrył drukarnię przed Leonem Lipskim, członkiem ostatniego kierownictwa partii, gdy ten nie chciał uznać decyzji Kominternu ${ }^{24}$.

Napięcie pomiędzy dyscypliną a zagubieniem towarzyszyło nie tylko „zawodowym rewolucjonistom". Jakub Berman, nieetatowy asystent Ludwika Krzywickiego, rugał żonę, gdy ta wyraziła wątpliwości co do procesów moskiewskich, mówiąc, że ma poglądy „jak z magla" - a zatem pozbawione pryncypialności i konsekwencji, które powinny charaktery-

\footnotetext{
${ }^{20}$ AAN, ZRDRR, R-114, Edwarda Orłowska, 27 XI 1961, k. 27-31.

${ }^{21}$ Skończyło się to dla niego ponadpięcioletnim pobytem w niemieckich obozach. Sam Izydorczyk wspominał tylko, że przekonywał towarzyszy o bezsensie przeciwstawiania się decyzjom Kominternu w sprawie rozwiązania partii. AAN, ZRDRR, R-191, Jan Izydorczyk, 22 X 1965, k. 6.

${ }^{22}$ AAN, ZRDRR, R-36, Wilhelm Billig, 26 XI 1956, k. 10.

${ }^{23}$ AAN, ZRDRR, R-191, Leon Bielski, 22 X 1965, k. 49-53.

${ }^{24}$ AAN, Zbiór Akt Osobowych Działaczy Ruchu Robotniczego (ZAODRR), 11294, podteczka 1., Ferdynand Chaber, życiorys, X 1967, k.2.
} 
zować rewolucjonistów (Tychowa, 2016, s. 22). Pelagia Lewińska, nienależąca do KPP, ale silnie z nią związana krakowska działaczka harcerska, pisała po latach, że „poddani jednostronnej i niekwestionowanej w rezultacie informacji ulegliśmy zaślepieniu, udzielając pełnego kredytu moralnego i politycznego kierownictwu Międzynarodówki i KPZR ${ }^{25}$. Wyłamać się z linii frontu - to dezercja (...)"26. Rozpacz zapanowała w wileńskim środowisku Zjednoczenia Lewicy Akademickiej „Front” grupującym młodych inteligentów, wyjątkowym z uwagi na ich skomplikowane drogi do komunizmu i sympatię otoczenia, nie bez podstaw uważającego ich za intelektualną elitę Uniwersytetu Stefana Batorego (Filipajtis, 1965; Kurski, 1999). Doktor biologii Kazimierz Petrusewicz wspominał: „Cios niezrozumiały, nie do wytłumaczenia. Coś, dla czego żyjemy, wali się w gruzy. (...) Jesteśmy sami (...). Są towarzysze z byłych instancji, ale to są tylko towarzysze, bo nie stoi za nim autorytet: partia" (Petrusewicz, 1969, s. 509).

Komintern zapowiedział, że jakakolwiek oddolna próba odbudowy organizacji będzie uznawana za prowokację (Czubiński, 1985, s. 267). Komuniści znaleźli się w napięciu pomiędzy tym zakazem a własną wolą walki. Lokalni działacze wiejscy, tacy jak Jan Klecha i Franciszek Zając, próbowali wpływać ideowo na spółdzielnie rolnicze albo propagować wśród chłopów postępową prasę ${ }^{27}$. Pończoszarka Irena Piwowarska spotykała się z komunistami ze swojej fabryki „dla przedyskutowania zagadnień politycznych, które poprostu się piętrzy$\nmid y^{\prime \prime 28}$. Kilku warszawskich inżynierów - Tadeusz Gede, Mieczysław Popiel, Bolesław Rumiński i Marian Spychalski - uformowało luźny krąg, w którym dyskutowano, zbierano pieniądze na więźniów politycznych, myślano o wydawaniu pisma ${ }^{29}$.

\section{Na wolności i u władzy}

Trzydzieści jeden osób, czyli mniej więcej 7\% całej elity partyjno-rządowej oraz 13\% komunistów, sympatyków i czerwonoarmistów albo osobiście doświadczyło przed wojną represji stalinowskich $^{30}$, albo przeżyło zamordowanie bądź uwięzienie bliskich. Zakres tego doświadczenia był jednak znacznie szerszy. Hekatomba kierownictwa oraz rozwiązanie partii wykształciły w komunistach zestaw szczególnych, nierzadko paradoksalnych dyspozycji.

\footnotetext{
${ }^{25}$ Anachronizm w cytacie - WKP(b) zmieniła nazwę na Komunistyczna Partia Związku Radzieckiego dopiero w 1952 r.

${ }^{26}$ P. Lewińska, Komuniści pod obstrzałem z dwóch różnych pozycji, niepublikowane wspomnienia, kopia w zbiorach autora, s. 83.

${ }^{27}$ AAN, BSK, 237/XXIII-881, Jan Klecha, życiorys, b.d., k. 10; AAN, BSK, 237/XXIII-643, Franciszek Zając, życiorys, 12 IX 1953, k. 12.

${ }^{28}$ AAN, KC PZPR, Centralna Kartoteka (CK), CKXX/4963, Irena Piwowarska, życiorys, b.d., k. 29.

${ }^{29}$ AAN, CK, CKXX/9752, Tadeusz Gede, życiorys, 1949, k. 13-14.

${ }^{30}$ Kilka innych osób trafiło do łagrów, więzień albo na zesłanie w latach 1940-1941.
} 
Łukasz Bertram Uciec? Dokąd? I przed czym? Doświadczenie represji stalinowskich w biografiach...

Członkowie EPR represjonowani w ZSRR opuścili najczęściej obozy lub miejsca osiedlenia w 1944/45 r. i niemal z marszu zajmowali wysokie stanowiska polityczne: Mazur został kierownikiem ważnego Wydziału Organizacyjnego KC Polskiej Partii Robotniczej (PPR), Kowalczyk redaktorem PPR-owskich pism, a Budzyńska i Siekierska trafiły do kadry Centralnej Szkoły Partyjnej. Po 1948 r. i powstaniu Polskiej Zjednoczonej Partii Robotniczej (PZPR) w jej Biurze Politycznym (BP) zasiadali Mazur i Rokossowski. Dziewięcioro represjonowanych było wtedy członkami lub zastępcami członków KC (jedynie Budzyńska znalazła się tam po śmierci Stalina). Pięć osób (Kowalczyk, Kubowska, Mazur, Staszewski, Tokarski) kierowało wydziałami i podobnymi jednostkami KC, a trzy (Feder, Siekierska, Zajączkowska) pełniło funkcje zastępców. Po czterech było ministrami (Modzelewski, Rokossowski, Tokarski i Wolski) oraz wiceministrami (Bordziłowski, Korczyc, Kotlarski, Staszewski). Jankowska zasiadała w Prezydium Centralnej Komisji Kontroli Partyjnej, a Półturzycki został wiceprzewodniczącym Państwowej Komisji Planowania Gospodarczego. Wysokie funkcje sprawowali również ci, którzy w czystce stracili bliskich: Zawadzki został członkiem BP, wicepremierem i przewodniczącym Rady Państwa, Radkiewicz członkiem BP i ministrem bezpieczeństwa publicznego. Niżej sytuowali się np.: H. Kamińska - zastępczyni kierownika Wydziału Historii Partii czy Tkaczow - wiceminister rolnictwa. W tym sensie członkowie EPR byli odpowiednikami ukształtowanej w drugiej połowie lat 30. elity radzieckiej - zawdzięczającej Stalinowi swój awans na miejsce „starych bolszewików” (Fitzpatrick, 1979; Nagle, 1975, ss. 9-11; Werblan, 2009, ss. 15-19; 52; Wintrobe, 2000, s. 227).

Ludzie ci funkcjonowali jednak w schizofrenicznych warunkach. Budowali porządek w wielkim stopniu wzorowany na systemie odpowiedzialnym za ich nieszczęścia. Łagierniczka Kubowska kierowała Biurem/Sekretariatem KC za rządów Bieruta, Ochaba i Gomułki, ciesząc się ich zaufaniem (Werblan, 2009, s. 123). Rutkiewicz, w czasie gdy jej brat siedział jeszcze w obozie, protokołowała posiedzenia BP. Budzyńska przywoływała prawdziwie surrealistyczną scenę, gdy Bierut na jednym z posiedzeń z atencją wspominał zamordowanych działaczy KPP, oficjalnie wciąż noszących piętno prowokatorów (Torańska, 2004, ss. 47-48). Jednak co do zasady komuniści nie mieli możliwości otwartego przeżywania żałoby i wyrażania niepożądanych poglądów. Przy wypełnianiu ankiet personalnych sugerowano im, by nawet w tego typu wewnętrznych dokumentach nie odnotowywać represji w ZSRR. Kowalczyk określił czas obozowy jako pracę „w różnych instytucjach gospodarczych”, a Feder - jako „przerwę w pracy”. W ankietach Kotlarskiego czytamy o "różnych pracach” lub okres ten jest w ogóle pominięty. Inaczej zachowały się Jankowska i Kubowska, które pisały wprost 
o uwięzieniu. Zajączkowska przyjęła wersję pośrednią, odnotowując, że w latach 1937-1945 pracowała w budzącym oczywiste skojarzenia Magadanie. Feder i Kowalczyk dopiero w połowie lat 60. przyznali się do "więzienia i obozu” oraz „przymusowego pobytu"31. Modzelewski o swoich losach opowiedział synowi na kilka miesięcy przed śmiercią w 1954 r. (Modzelewski \& Werblan, 2017, s. 63). Mimo że na XX zjeździe partii radzieckiej (1956) ogłoszono oficjalnie rehabilitację KPP, to np. życiorys Kubowskiej, który na jej pogrzebie w 1959 r. przypominał przedstawiciel KC, wciąż był niepełny: fragment, gdzie chronologicznie powinien znaleźć się okres łagrowy, został oderwany od kartki, a rozpoczynające następną stronę zdanie: „Wszystko to nie złamało towarzyszki Geni" - wykreślone ${ }^{32}$.

\section{Paradoksy wierności}

W tekście tym z oczywistych względów nie zajmuję się tymi, którzy pod wpływem doświadczeń lat 1937-1938 zerwali z komunizmem. Ponadto trzeba mieć na uwadze, że większość zarówno komunistów, jak i członków powojennej elity nie pozostawiła rozbudowanych narracji na temat swoich ówczesnych poglądów i emocji. Mimo to można spróbować pokazać, jakie mechanizmy sprawiały, że członkowie EPR, a także setki ich towarzyszy, po tak traumatycznym doświadczeniu pozostali aktywnymi i zaangażowanymi uczestnikami ruchu komunistycznego - a także to, jakie strategie życiowe przyjmowali po wojnie.

W 1938 r. zdezorientowani komuniści znaleźli się w sytuacji anomii, załamania związanego z silną rozbieżnością pomiędzy normami i celami kulturowymi a społecznie ustrukturyzowanymi możliwościami działania członków grupy zgodnie z tymi normami (Merton, 2002, s. 226). W tym kontekście na szczególny paradoks zwrócił uwagę William J. Chase. Podkreślając głębokość lęku i niepewności, które zapanowały w świecie komunistycznym na fali czystek, skonstatował, że Stalin - już wtedy jawiący się jako postać o ponadludzkiej skali - mógł być postrzegany jako zagrożenie, ale też jako paradoksalny obrońca przed chaosem. Później ten ponadludzki wymiar - wraz z wiarą w słuszność radzieckiej drogi - umocniło wojenne zwycięstwo nad nazizmem (Chase, 2002, ss. 32, 404-405). Tę dwoistość widać w zapiskach

\footnotetext{
${ }^{31}$ AAN, CK, CKXX/6256, Teodora Feder, ankieta, 12 XII 1948, k. 11; ankieta, 25 XI 1965, k. 26; AAN, BSK, 237/XXIII-876, Ludwika Jankowska, kwestionariusz, 5 V 1945, k. 5; AAN, BSK, XXIII-409, Władysław Kotlarski, kwestionariusz, 3 I 1946, k. 8; ankieta 23 III 1949, k. 12; AAN, CK, CKXX/11476, Józef Kowalczyk, życiorys, 30 I 1946, k. 8; ankieta, 7? I 1964, k. 23; AAN, BSK, 237/ XXIII-146, Eugenia Kubowska, życiorys, b.d., k. 13; AAN, BSK, 237/XXIII-436, Elżbieta Zajączkowska, kwestionariusz 14 IX 1945, k. 13; ankieta (1948/1949), k. 17.

${ }^{32}$ AAN, BSK, 237/XXIII-146, k. 10-12.
} 
Matwina, który stracił wuja, w 1942 r. próbował dostać się do wojska Andersa - a śmierć Stalina przeżył mocniej niż śmierć własnego ojca ${ }^{33}$.

Dla wielu członków ruchu odejście byłoby psychologicznie niewykonalne - socjalizowali się przecież w przekonaniu, że otaczający ich świat jest wrogi. Niektórzy odcięli się od dotychczasowych punktów oparcia: rodzin, wykształcenia, profesji. Idea uporządkowała ich świat, zaś partia nadała poczucie dziejowej sprawczości, a w niektórych wypadkach umożliwiła awans społeczny (i to już przed wojną, gdyż nawet podziemny "zawodowy rewolucjonista" był w istocie pracownikiem umysłowym). Niektórzy znaleźli się wręcz w biograficznej pułapce, w której jedyną bliską wspólnotą, spójnym systemem ideologicznym, zawodem, który znali, był komunizm, a ZSRR, jakikolwiek by był, stanowił jedyną tarczę przed reakcją i faszyzmem w świecie postrzeganym jako całkowicie spolaryzowany (Holzer, 2001). Partia była dla nich, jak pisałem wyżej, czymś więcej niż tylko organizacją. W 1945 r. M. Kamińska napisała w życiorysie: „całe swoje życie oddałam partji i całą siebie zawdzięczam partii”34.

Po 1944/45 r. kolejnym czynnikiem ułatwiającym pozostanie w ruchu komunistycznym był entuzjazm przekształcania Polski. Dla Feder w porównaniu z ZSRR była ona rajem ${ }^{35}$. Budzyńska wierzyła jeszcze, że „sama idea jest słuszna, a to co było w Związku - to deformacje (...). Byłam przekonana, że u nas będzie inaczej”. Ponadto „[z] samego dna, z otchłani beznadziei, gdzie wciąż trzeba było walczyć o to, aby nie utracić resztek człowieczeństwa, nagle wydostałam się na świat (...). I nagle stał się cud... stałam się pełnoprawnym człowiekiem, jak gdyby nowo narodzonym: moje córki nie są dziećmi „,wroga ludu”, mnie otaczają serdeczni ludzie, mam trudną, ale ciekawą pracę. I wszystko to zawdzięczam partii (...)" (Budzyńska, 1997, ss. 458-459). Siekierskiej uporać się z osobistą tragedią pomogło to, że Warszawa w 1945 r. kojarzyła jej się z Moskwą początku lat 20., "gdy widziało się ludzi wychudzonych lecz z płonącym wzrokiem". Wychowując nowe kadry, ,"spragniona działalności”, odzyskała „ludzką i partyjną przydatność"36.

Powojenne postawy wielu członków EPR wymykają się jednoznacznym klasyfikacjom. Pryncypialna i odważna rewolucjonistka Maria Kamińska w 1945 r. odcięła się od swojego zamordowanego przyjaciela Tadeusza Żarskiego, gdyż „usiłował, jak to się w szereg lat później okazało, stworzyć grupę antypartyjną na usługach sanacji137. Czy szczerze w to wierzyła, czy przyjęła, że prawdą jest to, co mówi Partia, czy może uczyniła to całkowicie wbrew sobie?

\footnotetext{
${ }^{33}$ AAN, Akta Władysława Matwina, 16, Władek - „Autobiografia”, wrzesień 1994, s. 3.

${ }^{34}$ AAN, KC PZPR, CKXX/4776, Maria Eiger, życiorys, 15 III 1945 r., k. 18.

${ }^{35}$ Relacja Pawła Mandaliana...

${ }^{36}$ AAN, ZAODRR, 10415, podteczka 3., Jadwiga Siekierska, Niezapomniane lata, niezapomniana szkoła, k. 30, 35.

${ }^{37}$ AAN, CK, CKXX/4776, Maria Eiger (Kamińska), życiorys, 15 III 1945, k. 18.
} 
Kilka lat później, gdy partia napiętnowała kolejnego wroga - Gomułkę - sporządziła na niego donos (Spałek, 2014, ss. 699-702). Kubowska, zaufana przywódcy partii, bardzo sprzeciwiała się decyzji przyjaciółki, która pod koniec lat 40. podjęła pracę w MBP. Choć w tym okresie nie wyrażała rozgoryczenia, to w ostatnich tygodniach przed śmiercią właśnie z wspomnianą przyjaciółką rozmawiała o swoich najtrudniejszych przeżyciach (Zatorska, 1985, ss. 216-217, 304, 374). Tak jak w wypadku wielu innych komunistów, prawdopodobnie także w tym wypadku nigdy nie dowiemy się, jak oceniała swoje wybory. O obozie nie rozmawiała nawet z synem, natomiast w przeciwieństwie do Matwina śmierć Stalina przyjęła bardzo spokojnie ${ }^{38}$.

Ciężko doświadczona przez stalinizm Jankowska zajmowała nieprzychylne stanowisko wobec zwalnianych z więzień "gomułkowców", czyli ofiar kolejnego polowania na "wroga wewnętrznego". Nie czuła z nimi nic wspólnego - czy bała się to okazać? Gdy Chruszczow potępił „kult jednostki”, a KPP została zrehabilitowana, jej postawa zmieniła się całkowicie (Sowińska, 2017, ss. 297, 306, 310-311). Dostosowała się do nowego kursu - czy wreszcie zniknął strach? Paradoksalna była również biografia Wolskiego. Po wyjściu z łagru oraz układzie Sikorski-Majski (1941) próbował nawiązać kontakt z przedstawicielami rządu emigracyjnego w ZSRR, najprawdopodobniej na polecenie NKWD (Przewłocki, 2005) ${ }^{39}$. W latach 40. pełnił znaczące, choć nie najwyższe funkcje, a w 1950 r. podjął próbę wystąpienia przeciwko kierownictwu PZPR, za co został wyrzucony z KC i partii. Wcześniej poszukiwał poparcia dla swoich planów u „towarzyszy radzieckich", co mu się ostatecznie nie udało (Szumiło, 2014, ss. 279-284). Nawet w czasach głębokiego stalinizmu nie bał się opowiadać o obozach (Kott, 1995, ss. 191-192) ${ }^{40}$. Jak się wydaje, pobyt w łagrze nie stępił jego ambicji i dyspozycji do politycznych gier.

\section{Po różnych stronach}

Według Aleksandra Wata ludzie KPP zachowali w pamięci "głęboką czułość" dla wymordowanych liderów (Wat, 1990, ss. 130, 233). Nienawidzili ZSRR za tę zbrodnię oraz hańbę, jaką było rozwiązanie partii. Uczucia te mogły się ujawnić dopiero w 1956 r. Czesław Miłosz pisał zaś, że jednym z powodów, dla których Polska nawet w najgorszych latach stalinizmu

\footnotetext{
${ }^{38}$ Rozmowa telefoniczna autora z Jerzym Kubowskim...

${ }^{39}$ K. Banaś, Władysław Wolski. Meandry kariery komunistycznego działacza 1944-1950, praca magisterska, Uniwersytet Łódzki, kopia w zbiorach autora (Banaś, 2016, ss. 27-29).

${ }^{40}$ Podczas jednego z zebrań wspomnieniowych w Zakładzie Historii Partii poczynił uwagę, że w związku z pobytem w radzieckim obozie ma bardziej obiektywne spojrzenie na rzeczywistość lat 30. AAN, R-143, Władysław Wolski, 16 III 1964, k. 120.
} 
„przechowała coś ze współczucia dla bezbronnych”, była „głucha nienawiść starych komunistów do oprawcy" (Miłosz, 1990, s. 315). Pamięć o latach 1937-1938 może być też jednym z wyjaśnień, dlaczego w latach 50. walka z "odchyleniem prawicowo-nacjonalistycznym” nie toczyła się tak gwałtownie, jak mogła (Modzelewski \& Werblan, 2017, s. 75). Wydane w 1958 r. wspomnienia Romany Granas pełne są niezwykle ciepłych portretów jej dawnych towarzyszy, a kończy je dramatycznie urwane zdanie: „A potem nastąpił rok 1937" (Granas, 1958, s. 113). Ona i Budzyńska należały w 1956 r. do grona aktywnych zwolenników demokratyzacji, a po kilkunastu latach były już, tak jak Feder i Siekierska, sympatyczkami opozycji. Podobną drogę pokonał Staszewski, który - zanim nastała odwilż po śmierci Stalina - dał się jednak poznać jako gorliwy realizator radykalnej polityki kierownictwa PZPR (Budzyńska, 1997, ss. 474-489; Torańska, 2004, ss. 193-211). Oczywiście źródeł tych postaw nie można upatrywać tylko w pamięci wielkiej czystki, ale również w zawiedzionych nadziejach po Październiku 1956 czy szoku Marca 1968.

Taka ewolucja nie nastąpiła jednak u wszystkich ofiar. W odmiennym niż u Wata czy Miłosza kierunku idą interpretacje brytyjskiego historyka Roberta Conquesta, podkreślającego podwójną naturę komunistycznej moralności: niechęć do zabijania "swoich" oraz obojętność dla cierpień wrogów - niekomunistów (Conquest, 1997, ss. 38-40). W PPR i PZPR znaleźli się również tacy, których upoiła władza lub którzy silnie internalizowali normy i wartości stalinizmu nie pomimo autorytaryzmu, represyjności i radykalnego stosunku do "wroga” - ale właśnie z ich powodu. W 1944 r. w charakterystyce Tokarskiego zapisano, że z powodu represji „do chwili obecnej nie przezwyciężył swej nieufności do oficerów rosyjskich i członków WKP(b). W rozmowach z pracownikami aparatu politycznego Brygady ujawnił trwogę i bojaźń hegemonji WKP(b) w partyjnej organizacji Armji Polskiej" ${ }^{42}$. W 1956 r. był jednak, podobnie jak Trusz, kojarzony z antyreformatorską i mocno związaną z ZSRR

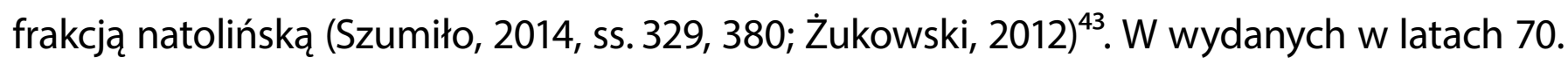
wspomnieniach okres łagrowy zamknął krótką wzmianką i stwierdzeniem, że nie chce go wspominać (Tokarski, 1973, ss. 222-223). Czy uczynił tak z cenzuralnej konieczności, czy z przekonania ${ }^{44}$ ? Rokossowskiego i Mazura, którzy przeszli brutalne tortury, uważano

\footnotetext{
${ }^{41}$ Relacja Łukasza Bobińskiego nagrana przez autora, 15 IV 2016, nagranie w zbiorach autora; relacja Pawła Mandaliana...

${ }^{42}$ AAN, BSK, 237/XXIII-888, mjr Sokołowski, charakterystyka, 26 VI 1944, k. 15.

${ }^{43}$ "Natolińczycy" w 1956 r. postulowali jedynie niewielkie korekty polityczne, głównie personalne, w przeciwieństwie do „puławian", czyli działaczy wzywających do poważniejszej liberalizacji systemu.

${ }^{44}$ Dygresyjnie można wspomnieć, że po wojnie ożenił się z Jankowską. Jakie znaczenie w takich osobistych relacjach miała pamięć o podobnych doświadczeniach, trudno niestety zgadywać.
} 
w latach 50. za strażników interesów radzieckich, choć drugi z nich podobno nienawidził Stalina (Torańska, 2004, s. 123). Jedno nie musiało zresztą wykluczać drugiego. Znacznie bardziej jednoznacznie brzmi relacja Stanisława Brodzińskiego, w latach 30. czeladnika krawieckiego i lokalnego działacza KZMP ${ }^{45}$, który bezpośrednio nie otarł się o czystkę, w latach 50. należał do "natolińczyków”, a jeszcze pod koniec PRL tak mówił o stalinowskiej czujności wobec wroga, również we własnych szeregach: „Stalin jako przykład podał, że aby wybudować Dnieproges, potrzebna jest praca tysięcy ludzi, by go zniszczyć wystarczy jeden człowiek. (...) Tak rozumiałem wówczas Stalina i tak rozumiem go dzisiaj (... .)"46. Można w tym dostrzec świadectwo tego, jak ówczesna polityka przywódcy ZSRR, pełna rozmachu i brutalności przemiana społeczeństwa, mogła odpowiadać potrzebom niektórych jednostek ${ }^{47}$. Gdzieś pomiędzy tymi biegunami, z dala od frakcji, pozostawał Józef Kowalczyk, który do końca pozostał wierny Partii i nie żałował niczego ze swojego życia ${ }^{48}$. Również Ferdynand Chaber, tak zdyscyplinowany w 1938 r., do końca swojej kariery politycznej w latach 60. realizował politykę aktualnego kierownictwa (Rakowski, 1999, s. 77).

\section{Doświadczenie pokoleniowe}

Niezależnie od motywacji i obranych strategii, wszystkim opisywanym bohaterom prawdopodobnie długo towarzyszył strach: o siebie i przed samym sobą (Chase, 2002, ss. 228, 239). Oraz oczywiście przed Stalinem, NKWD, Związkiem Radzieckim, co paranoicznie łączyło się z fascynacją i miłością. Komuniści wyższego szczebla mogli mieć przekonanie, że sami mogli byli kandydatami na ofiary represji, i że uderzenie może przyjść znowu - choć niewykluczone, że starali się te myśli od siebie odsuwać, będąc przekonanymi o własnej niewinności. Przetrwanie nawet dla najbardziej wiernych nie było zagwarantowane, ale jeśli można było zwiększyć jego prawdopodobieństwo, to poprzez ścisłą dyscyplinę i konformizm wobec norm stalinowskich (Chase, 2002, s. 276). Lata 1937-1938 były dla polskich komunistów nauką nieufności i gotowości do wzajemnych oskarżeń (Samuś, 1995, s. 186).

Indywidualne przeżycia uwięzionej w łagrze żony rozstrzelanego członka KC KPP musiało być inne od tego, czego doświadczał sekretarz komórki na podrzeszowskiej wsi. Doświadczenia

\footnotetext{
${ }^{45}$ Komunistyczny Związek Młodzieży Polski - nazwa, którą w 1930 r. przyjął ZMK.

${ }^{46}$ AAN, ZAODRR, 8612, Stanisław Brodziński, relacja, 10 II 1987, k. 74.

47 Brodziński był w tym wyjątkowo konsekwentny: w latach 60. dołączył do nowej Komunistycznej Partii Polski, skupiającej dogmatyków uznających ekipę Gomułki za zdradziecką i rewizjonistyczną. Trafił nawet za to do więzienia.

${ }^{48}$ Korespondencja mailowa autora z Marią Rotstein.
} 
lat 1937-1938 nie przysłoniły całkowicie tych wcześniejszych, związanych z socjalizacją w ruchu komunistycznym - dla komunistów jako formacji były one jednak kluczowe. We wspomnieniach i historiografii nacisk kładzie się często na pierwszą z tych dat, czyli największe nasilenie aresztowań i egzekucji, jednak dla komunistów potężnym wstrząsem był również "fatalny rok 1938", w którym odebrano im Partię. Przeżycie to uznałbym za Janem Garewiczem (1985, ss. 138-153) za doświadczenie pokoleniowe, obejmujące pewną względnie zamkniętą grupę jako całość, stanowiące dla niej punkt odniesienia dla doświadczeń późniejszych i budujące pamięć zbiorową. Przy kolektywnym charakterze odnosiło się ono silnie do przeżyć indywidualnych, przede wszystkim takich jak doznawanie cierpienia, krzywdy oraz spotkanie ze złem. Różnica w zestawieniu z koncepcją Garewicza jest taka, że doświadczenie polskich komunistów nie zakładało jasnego opowiedzenia się po jednej stronie dychotomicznych wartości moralnych a raczej zagubienie i ambiwalencję - trudno też odnaleźć w nim pierwiastek katartyczny. Podstawowym efektem tego doświadczenia było raczej umocnienie i wytworzenie dyspozycji do specyficznej „pojętności” względem radzieckich bolszewików: z jednej strony szczerej internalizacji stalinowskiej ideologii i norm postępowania, z drugiej - strachu oraz umiejętności przystosowania się i skrywania głęboko swoich poglądów i uczuć.

\section{Bibliografia}

Banaś, K. (2016). Władysław Wolski: Meandry kariery komunistycznego działacza 1944-1950 (Praca magisterska). Uniwersytet Łódzki, Łódź.

Bertram, Ł. (2016). Wyrastanie z pałacu: Analiza narracji autobiograficznej Marii Kamińskiej (1897-1983). W D. Magier (Red.), To idzie młodość! Młodzież w ideologii i praktyce komunizmu (ss. 171-192). Lublin: Archiwum Państwowe w Lublinie, Towarzystwo Nauki i Kultury „Libra”.

Bertram, Ł. (2017). Widows of the Revolution: Women in Polish political elite 1949-1956. History of Communism in Europe, 8, 121-146.

Better, J. (2017). Dziecko Gułagu: Okruchy wspomnień z nieludzkiej ziemi. Warszawa: Agencja Wydawnicza CB.

Brzeziński, Z. (1956). The permanent purge: Politics in Soviet totalitarianism. Cambridge, MA: Harvard University Press. https://doi.org/10.4159/harvard.9780674732674

Budzyńska, C. (1997). Strzępy rodzinnej sagi. Warszawa: Żydowski Instytut Historyczny.

Chase, W. J. (2002). Enemies within the gates? The Comintern and the Stalinist repression, 1934-1939. New Haven, CT: Yale University Press.

Cimek, H. (1990). Komuniści, Polska, Stalin. Warszawa: Krajowa Agencja Wydawnicza.

Conquest, R. (1997). Wielki Terror (W. Jeżewski, Tłum.). Warszawa: Wydawnictwo Michał Urbański. 
Czubiński, A. (1985). Komunistyczna Partia Polski (1918-1938): Zarys historii. Warszawa: Wydawnictwa Szkolne i Pedagogiczne.

Filipajtis, E. (1965). Lewica Akademicka w Wilnie: 1930-pocz. 1935. Białystok: Białostockie Towarzystwo Naukowe.

Fitzpatrick, S. (1979). Stalin and the making of a new elite, 1928-1939. Slavic Review, 38(3), 377-402. https://doi.org/10.2307/2496711

Fitzpatrick, S. (2012). Życie codzienne pod rzqdami Stalina: Rosja radziecka w latach trzydziestych XX wieku (J. Gilewicz ,Tłum.). Kraków: Wydawnictwo Uniwersytetu Jagiellońskiego.

Furet, F. (1996). Przeszłość pewnego złudzenia: Esej o idei komunistycznej w XX w. (J. Górnicka-Kalinowska \& M. Ochab, Tłum.). Warszawa: Oficyna Wydawnicza Wolumen.

Garewicz, J. (1985). Pokolenie jako kategoria socjo-filozoficzna. W K. Murawski \& J. Rudniański (Red.), Na krawędzi epoki: Rozwój duchowy i działanie człowieka (ss. 138-153). Warszawa: Państwowy Instytut Wydawniczy.

Getty, J. A. (1985). Origins of the Great Purges: The Soviet Communist Party reconsidered 1933-1938. Cambridge: Cambridge University Press. https://doi.org/10.1017/CBO9780511572616

Getty, J. A., \& Naumov, O. (1999). The road to terror: Stalin and the self-destruction of the Bolsheviks 1932-1939. New Haven, CT: Yale University Press.

Gomułka, W. (1994). Pamiętniki (A. Werblan, Red.) (T. 1). Warszawa: Polska Oficyna Wydawnicza BGW. Granas, R. (1958). Gruba Ceśka. Warszawa: Iskry.

Halfin, I. (2003). Terror in my soul: Communist autobiographies on trial. Cambridge, MA: Harvard University Press.

Hirszowicz, M. (2001). Pułapkizaangażowania: Intelektualiści w służbie komunizmu. Warszawa: Scholar. Holzer, J. (2001). Jedyna ojczyzna proletariatu - ZSRR: W dobrym i złym to jest mój kraj. W T. Szarota (Red.), Komunizm: Ideologia, system, ludzie (ss. 9-16). Warszawa: Instytut Historii PAN, Neriton. Juzepczuk, M. (2017). Stefan Staszewski (1906-1989): Biografia polityczna (Praca doktorska). Instytut Historii UMCS, Lublin.

Kalicka, F. (1989). Dwa czterdziestolecia mojego życia. Warszawa: Czytelnik.

Kieszczyński, L. (1989). Represje wobec kadry kierowniczej KPP. W J. Maciszewski (Red.), Tragedia Komunistycznej Partii Polski (ss. 198-216). Warszawa: Książka i Wiedza.

Kieszczyński, L. (1992). Represje stalinowskie w ZSRR wobec działaczy polskiego ruchu robotniczego i ich rodzin w latach trzydziestych i połowy czterdziestych. W J. Itrich, J. Kancewicz, \& I. Koberdowa (Red.), Oblicza lewicy: Losy idei i ludzi (ss. 293-357). Warszawa: Towarzystwo Naukowe im. Adama Próchnika.

Kijek, K. (2017). Dzieci modernizmu: Świadomość, kultura i socjalizacja polityczna młodzieży żydowskiej w II Rzeczypospolitej. Wrocław: Wydawnictwo Uniwersytetu Wrocławskiego.

Kochański, A. (Oprac.). (2008). O faszystowsko-powstańczej, szpiegowskiej, dywersyjnej, defetystycznej i terrorystycznej działalności polskiego wywiadu w ZSRR (rozkaz nr 00485). Polityka i Społeczeństwo, 5, 201-219. 
Łukasz Bertram Uciec? Dokąd? I przed czym? Doświadczenie represji stalinowskich w biografiach...

Kołakowski, L. (2009). Główne nurty marksizmu (T. 2). Warszawa: Wydawnictwo Naukowe PWN. Kotkin, S. (1997). Magnetic mountain: Stalinism as a civilization. Berkeley: University of California Press. Kott, J. (1995). Przyczynek do biografii: Zawał serca. Kraków: Wydawnictwo Literackie.

Kowalski, J. (1975). Komunistyczna Partia Polski 1935-1938: Studium historyczne. Warszawa: Książka i Wiedza.

Krzemień, L. (1982). Kropla w potoku. Warszawa: Iskry.

Kurski, J. (1999, listopad 18, 25). Wileńska Lewica Akademicka „Front". Gazeta Wyborcza. Pobrano 9 czerwca 2018, z http://wyborcza.pl/1,75248,138364.html

Leder, S., \& Leder, W. (2005). Czerwona nić: Ze wspomnień i prac rodziny Lederów. Warszawa: Iskry. Lewin, M. (1985). Society, state and ideology during the first five-year plan. W M. Lewin, The making of the Soviet system: Essays in the social history of interwar Russia (ss. 209-240). New York, NY: Pantheon.

Levy, R. (2001). Ana Pauker: The rise and fall of a Jewish Communist. Berkeley: University of California Press. https://doi.org/10.1525/california/9780520223950.001.0001

Ludwińska, J. S. (1988). Życie nielegalne. Warszawa: Książka i Wiedza.

Maciszewski, J. (Red.). (1989). Tragedia Komunistycznej Partii Polski (J. Darczewska \& K. Smerd, Tłum.). Warszawa: Książka i Wiedza.

McDermott, K., \& Agnew, J. (1996). The Comintern: A history of international communism from Lenin to Stalin. Houndmills: Macmillan. https://doi.org/10.1007/978-1-349-25024-0

Merton, R. K. (2002). Teoria socjologiczna i struktura społeczna (E. Morawska \& J. Wertenstein-Żuławski, Tłum.). Warszawa: Wydawnictwo Naukowe PWN.

Miłosz, C. (1990). Rodzinna Europa. Warszawa: Czytelnik.

Modzelewski, K. (2013). Zajeździmy kobyłę historii: Wyznania poobijanego jeźdźca. Warszawa: Iskry. Modzelewski, K., \& Werblan, A. (2017). Polska Ludowa: Modzelewski, Werblan: Rozmawia Robert Walenciak. Warszawa: Iskry.

Müller, J.W. (2016). Przeciw demokracji. Idee polityczne w XX wieku w Europie (J. Majmurek, Tłum.). Warszawa: Wydawnictwo Krytyki Politycznej.

Nagle, J. D. (1975). A new look at the Soviet elite: A generational model of the Soviet system. Journal of Political and Military Sociology, 3, 1-13.

Nalewajko-Kulikov, J. (2009). Obywatel Jidyszlandu: Rzecz o żydowskich komunistach w Polsce. Warszawa: Instytut Historii PAN.

Naszkowski, M. (1965). Lata próby. Warszawa: Książka i Wiedza.

Nazarewicz, R. (1989). Od KPP do PPR (1938-1942): Kryzys polskiego ruchu komunistycznego w świetle dokumentów Międzynarodówki Komunistycznej. W J. Maciszewski (Red.), Tragedia Komunistycznej Partii Polski (ss. 146-197). Warszawa: Książka i Wiedza.

O bolszewizacji partii. (1955). W J. Kowalski, F. Kalicka, \& S. Zachariasz (Red.), KPP: Uchwały i rezolucje: T. 2. III-IV Zjazd (1924-1929) (ss. 122-139). Warszawa: Książka i Wiedza. 
Petrusewicz, K. (1969). Grupa wileńska, czyli „Front”. W L. Borkowicz i in. (Red.), Komuniści: Wspomnienia o Komunistycznej Partii Polski (ss. 488-510). Warszawa: Książka i Wiedza.

Priestland, D. (2007). Stalinism and the politics of mobilization: Ideas, power, and terror in inter-war Russia. Oxford: Oxford University Press.

Przewłocki, J. (2005). Wolski-Piwowarczyk w kujbyszewskiej Ambasadzie RP: Na marginesie „Listów z Rosji" prof. S. Kota. Zeszyty Historyczne, 2005(153), 138-146.

Radziejowski, J. (1976). Komunistyczna Partia Zachodniej Ukrainy 1919-1929: Węzłowe problemy ideologiczne. Kraków: Wydawnictwo Literackie.

Rakowski, M. (1999). Dzienniki polityczne 1967-1968. Warszawa: Iskry.

Samuś, P. (1995). Syndrom „oblężonej twierdzy” w Komunistycznej Partii Polski. W A. F. Grabski \& P. Samuś (Red.), Między wschodem a zachodem: Studia z dziejów polskiego ruchu i myśli socjalistycznej (ss. 183-201). Łódź: Wydawnictwo Uniwersytetu Łódzkiego.

Schatz, J. (1991). The generation: The rise and fall of the Jewish communists of Poland. Berkeley: University of California Press.

Schlögel, K. (2014). Terror i marzenie: Moskwa 1937 [E-book] (I. Drozdowska-Broering \& J. Kałążny, Tłum.). Poznań: Wydawnictwo Poznańskie.

Sewell, S. A. (2012). Bolshevizing communist women: The Red Women and Girls' League in Weimar Germany. Central European History, 45(2), 268-305. https://doi.org/10.1017/S0008938912000052

Shore, M. (2008). Kawior i popiół: Życie i śmierć pokolenia oczarowanych i rozczarowanych marksizmem. Warszawa: Świat Książki.

Siekierska, J. (1960). Kartki z przeszłości. Warszawa: Iskry.

Simoncini, G. (1993). The Communist Party of Poland, 1918-1929: A study in political ideology. Lewiston, NY: Mellen Press.

Skilling, H. G. (1961). Gottwald and the Bolshevization of the Communist Party of Czechoslovakia (1929-1939). Slavic Review, 20(4), 641-655. https://doi.org/10.2307/3004097

Sowińska, S. (2017). Gorzkie lata: Z wyżyn władzy do stalinowskiego więzienia (Ł. Bertram, Red.). Warszawa: Ośrodek KARTA.

Spałek, R. (2014). Komuniści przeciwko komunistom: Poszukiwanie wroga wewnętrznego w kierownictwie partii komunistycznej w Polsce w latach 1948-1956. Poznań: Instytut Pamięci Narodowej.

Szumiło, M. (2014). Roman Zambrowski 1909-1977: Studium z dziejów elity komunistycznej w Polsce. Warszawa: Instytut Pamięci Narodowej.

Tokarski, J. (1973). Odległe i bliskie. Warszawa: Książka i Wiedza.

Torańska, T. (2004). Oni. Warszawa: Iskry.

Trusz, J. (1981). Z doświadczeń pokolenia. Warszawa: Książka i Wiedza.

Tychowa, L. (2016). Tak, jestem córkq Jakuba Bermana: Z Lucyna Tychową rozmawia Andrzej Romanowski. Kraków: Towarzystwo Autorów i Wydawców Prac Naukowych. 
Łukasz Bertram Uciec? Dokąd? I przed czym? Doświadczenie represji stalinowskich w biografiach...

Wat, A. (1990). Mój wiek: Pamiętnik mówiony (T. 1). Warszawa: Czytelnik.

Weitz, E. D. (1997). Creating German communism, 1890 - 1990: From popular protests to socialist states. Princeton, NJ: Princeton University Press.

Weissberg-Cybulski, A. (1990). Wielka Czystka (A. Ciołkosz, Tłum.). Warszawa: Wers.

Werblan, A. (2009). Stalinizm w Polce. Warszawa: Towarzystwo Wydawnicze i Literackie.

Wieczorkiewicz, P. (2016). Łańcuch śmierci: Czystka w Armii Czerwonej 1937-1939. Poznań: Zysk i S-ka.

Wintrobe, R. (2000). The political economy of dictatorship. Cambridge: Cambridge University Press.

Wolski, W. (1980). Kartki kontrowersyjne (C. Bobińska-Wolska, Oprac.). Kraków: Wydawnictwo Literackie.

Zajcew, O. (2015). Podziały frakcyjne w Komunistycznej Partii Zachodniej Ukrainy. W M. Szumiło \& M.Żukowski (Red.), Elity komunistyczne w Polsce (ss. 103-118). Warszawa: Instytut Pamięci Narodowej.

Zambrowski, R. (1965). Gdy już nie było partii. W L. Pasternak (Red.), Bereziacy (ss. 401-414). Warszawa: Książka i Wiedza.

Zatorska, H. (1985). Spoza smugi cienia: Wspomnień ciąg dalszy. Kraków: Wydawnictwo Literackie. Żukowski, M. (2012). „Klęska starego komunisty”: Październik ‘56 w relacji Jana Trusza. Historia iŚwiat, 1, 233-238.

\section{To run? Where? And from what? The experience of Stalinist repressions in the biographies of the members of the Polish party-government elite, 1949-1956}

This article is devoted to a specific political experience of Polish communists - Stalinist terror against their leadership in the second half of the 1930s and the dissolution of the Communist Party of Poland (KPP) following the resolution of the Presidium of the Comintern's Executive Committee (16 August 1938). The study is based on the analysis of the biographies of 214 members of the Polish communist movement in the interwar period, 22 fellow travellers and five Red Army officers, all of whom were members of the Polish party-government elite in the years 1949-1956. The article presents the stories of seventeen people who were arrested and imprisoned during the Stalinist purges, as well as the cases of those who lost their significant others: spouses and relatives. The author shows how the communists in Poland responded to the atmosphere of that time and how they reacted to the dissolution of the party. The last section of the article is devoted to the attitudes of members of the Polish party-government elite after the Second World War, when they actively participated in the establishment of the new socio-political order, and their collective memory related to the KPP's fate. Going beyond the historical description, this paper 
makes an attempt to interpret the phenomenon under consideration as a generational experience and the key element of political socialisation which shaped their disposition to specific and ambiguous submissiveness to their Soviet patrons: an internalised faith in the system combined with an ability to accommodate.

\title{
Keywords:
}

communism; USSR; Communist Party of Poland; purge; experience; terror; socialisation; elite

\section{Uciec? Dokq̨? I przed czym? Doświadczenie represji stalinowskich w biografiach członków polskiej elity partyjno-rządowej lat 1949-1956}

\begin{abstract}
Tematem artykułu jest szczególny element doświadczenia politycznego polskich komunistów, jakim był stalinowski terror wobec ich grupy przywódczej w drugiej połowie lat 30. oraz rozwiązanie Komunistycznej Partii Polski uchwałą Prezydium Komitetu Wykonawczego Kominternu z 16 sierpnia 1938 r. Bazą źródłową tekstu są biografie 214 członków międzywojennego polskiego ruchu komunistycznego, 22 jego sympatyków oraz 5 oficerów Armii Czerwonej, którzy w latach 1949-1956 należeli do polskiej elity partyjno-rządowej (EPR). Autor przedstawia losy 17 osób, które w okresie czystek stalinowskich były aresztowane i osadzone w więzieniach lub łagrach, a także odnotowuje wszystkie przypadki utraty przez członków EPR ich znaczących innych: partnerów i krewnych. Pokazuje, w jaki sposób komuniści w Polsce odbierali ówczesną atmosferę i w jaki sposób reagowali na rozwiązanie partii. Ostatnia część artykułu poświęcona jest postawom represjonowanych członków EPR w okresie powojennym, kiedy uczestniczyli oni w budowie nowego porządku polityczno-społecznego, oraz ich pamięci zbiorowej związanej z losem KPP. Wychodząc poza opis historyczny, tekst stanowi próbę interpretacji przeżyć członków analizowanej grupy z drugiej połowy lat 30. w kategorii doświadczenia pokoleniowego oraz kluczowego elementu socjalizacji politycznej, kształtującego dyspozycję do specyficznej i niejednoznacznej pojętności względem patronów radzieckich: zinternalizowanej wiary w system, współwystępującej z umiejętnościami przystosowania się.
\end{abstract}

\section{Słowa kluczowe:}

komunizm; ZSRR; Komunistyczna Partia Polski; czystka; doświadczenie; terror; socjalizacja; elita

\section{Citation:}

Bertram, Ł. (2018). Uciec? Dokąd? I przed czym? Doświadczenie represji stalinowskich w biografiach członków polskiej elity partyjno-rządowej lat 1949-1956. Adeptus, 2018(12). https://doi .org/10.11649/a.1760 